\title{
Keterkaitan Desain Ruang Publik Dengan Perilaku Pengunjung Mal di Yogyakarta (Kasus: Ambarrukmo Plaza dan Galeria Mall)
}

\author{
Nimas Sekarlangit \\ Program Studi Arsitektur, Fakultas Teknik, Universitas Atmajaya Yogyakarta \\ nimas.sekarlangit@uajy.ac.id
}

\begin{abstract}
ABSTRAK
Gaya hidup masyarakat perkotaan yang lebih memilih berbelanja di pusat perbelanjaan daripada pasar tradisonal membuat pembangunan pusat perbelanjaan di kota-kota besar semakin besar. Perbedaan tingkat golongan mall dan bentuk ruang publik yang ditawarkan oleh mall terkait dengan perilaku pengunjung. Aktivitas pengunjung dapat berbeda-beda tergantung dengan cara mereka mendeskripsikan ruang-ruang publik yang ditawarkan di dalam mall. Pada penelitian ini menggunakan dua mal yang berada di Jalan Adisucipto Yogyakarta yaitu Galeria Mall dan Ambarrukmo Plaza. Pemilihan dua mall di didasarkan pada letaknya yang berada di jalur utama keluar dan masuk kota Yogyakarta. Permasalahan yang diangkat adalah desain ruang publik pada mall, perilaku pengunjung pada ruang publik mall, keterkaitan desain ruang publik dengan perilaku pengunjung pada mall. Metode yang digunakan adalah deskriptif kualitatif dengan merekam segala aktivitas dan desain ruang publik yang ada di dalam mall serta menganalisis keterkaitannya. Hasil dari penelitian ini adalah Ambarrukmo Plaza dan Galeria Mall menggunakan ruang sosiopetal dengan pengaturan ruangan yang cenderung untuk menyatukan individu sehingga tercipta interaksi sosial. Hal itu berfungsi untuk menciptakan efek psikologis kepada pengunjung sehingga mereka tidak merasa terasing di lingkungan yang telah dibuat oleh pengelola mall.
\end{abstract}

Kata kunci: Perilaku pengunjung, ruang publik

ABSTRACT

The lifestyle of urban people who prefer shopping in shopping centers rather than traditional markets makes the construction of shopping centers in big cities even bigger. The difference in mall level and the shape of public space offered by the mall are related to visitor behavior. Visitor activities can vary depending on the way they describe the public spaces offered in the mall. This study uses two malls located on Yogyakarta's Adisucipto Road, namely Galeria Mall and Ambarrukmo Plaza. The selection is due to its location on the main road of Yogyakarta. This research aims to study the relationship between the public spaces design and the behavior of visitors at the mall. The method used is descriptive qualitative by recording all activities and designs of public spaces in the mall and analyzing their interrelationships. The results show that Ambarrukmo Plaza and Galeria Mall use a sociopetal space with regulatory spaces that tend to unite individuals to create social interaction. This service is a psychological effect on visitors so that they do not feel alienated in the mall.

Keywords: Consumer behavior, public space

\section{Pendahuluan}

Wajah kota Yogyakarta yang tampak seiring berkembangnya fasilitas komersial yang mewadahi kegiatan perdagangan kini telah mendapat sentuhan gaya hidup urban karena tidak hanya mengembangkan kegiatan komersial pada tingkatan pasar tradisional 
saja, tetapi sudah dalam fase mulai memasuki lingkup berdirinya mal-mal dan pusatpusat perbelanjaan. Wajah urban seperti ini dinilai sudah mulai dapat terdeteksi sejak tahun 1988, sejak dibukanya sebuah department store Matahari pertama di Malioboro yang cukup menjadi pemicu potensi komersil Malioboro saat itu. Lalu di tahun 1990, dibuka pula department store Gardena di Jalan Solo, kemudian Ramai Mall pada tahun 1991 di Malioboro, tahun 1992 Stockwell di Jalan Solo, tahun 1993 beroperasinya Malioboro Mall serta Ramayana di Malioboro dan Galeria Mall di Jalan Sudirman, tahun 1995 Beringharjo Center di pasar Beringharjo, tahun 2004 dibuka Jogjatronik di Jalan Brigjen Katamso, hingga tahun 2006 dengan dibukanya Sapphir Square dan Ambarrukmo Plaza yang keduanya terletak di Jalan Solo (Alexander, 2015).

Gaya hidup masyarakat perkotaan yang lebih memilih berbelanja di pusat perbelanjaan daripada pasar tradisonal membuat pembangunan pusat perbelanjaan di kota- kota besar semakin besar. Masyarakat memilih berbelanja di pusat-pusat perbelanjaan karena mendapatkan kenyamanan dan keamanan dalam berbelanja., hal ini didapat karena pusat-pusat perbelanjaan memiliki pola tata ruang yang lebih teratur sehingga membentuk pola sirkulasi yang baik untuk pengunjungnya (Syoufa dan Hapsari, 2014).

\section{Bahan dan Metode}

\subsection{Latar Belakang}

Ruang publik merupakan tempat bertemunya bermacam aktivitas dari berbagai pengguna. Dalam interaksinya para pengguna menghadirkan aspek perilaku yang beragam. Ruang publik pada mall adalah ruang yang menjadi area milik mall yang dapat diakses oleh semua pengunjung dengan berbagai kegiatan yang dilakukan didalam mall. Ruang publik pada mall terdiri dari selasar, atrium dan food court. Perbedaan tingkat golongan mall dan bentuk ruang publik yang ditawarkan oleh mall terkait dengan perilaku pengunjung. Aktivitas pengunjung dapat berbeda-beda tergantung dengan cara mereka mendeskripsikan ruang-ruang publik yang ditawarkan di dalam mall.

Pada penelitian ini menggunakan dua mall yang berada di Jalan Adisucipto Yogyakarta yaitu Galeria Mall dan Ambarrukmo Plaza. Pemilihan dua mall di didasarkan pada letaknya yang berada di jalur utama keluar dan masuk kota Yogyakarta serta berada di area komersial, hunian dan pendidikan, sehingga memiliki banyak pengunjung dan beragam. Berikut adalah perilaku pengunjung yang berada di Galeria Mall dan Ambarrukmo Plaza.

\subsubsection{Galeria Mall}

Pengunjung yang datang berkelompok sedang duduk di atrium tengah dengan bentuk tempat duduk melingkar sambil bercakap-cakap dan melihat ke arah atrium utama.
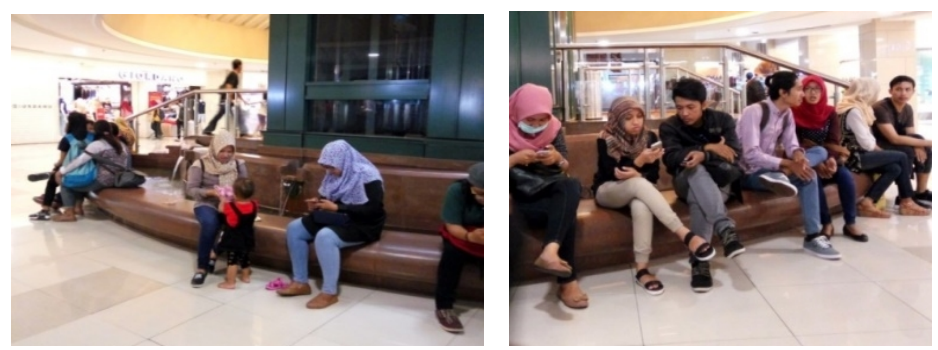

Gambar. 1 Perilaku Pengunjung Pada Area Duduk Galeria Mall (Sumber : Dokumen Pribadi, 3 Oktober 2016) 
Pengunjung sedang bersandar pada railing yang ada pada selasar sambil melihat ke arah atrium.
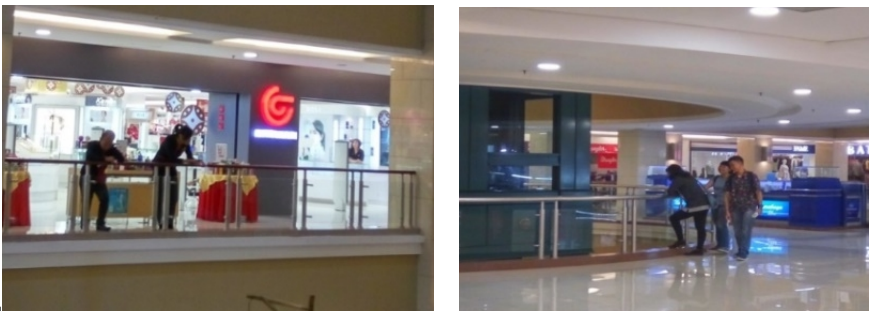

Gambar. 2 Perilaku Pengunjung Pada Railing Galeria Mall (Sumber : Dokumen Pribadi, 3 Oktober 2016)

Pengunjung sedang duduk di kursi yang berada di selasar lantai 2 dan berbatasan langsung dengan void atrium utama.
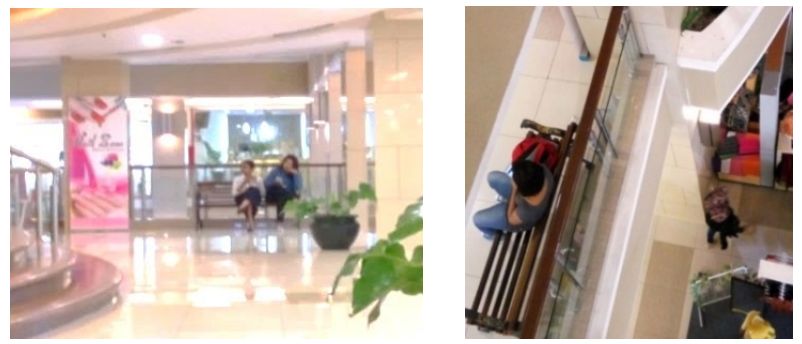

Gambar. 3 Perilaku Pengunjung Pada Area Duduk Galeria Mall (Sumber : Dokumen Pribadi, 3 Oktober 2016)

\subsubsection{Ambarrukmo Plaza}

Pengunjung yang datang secara berkelompok memanfaatkan railing pada selasar mall yang berada area sekitar atrium untuk bercakap-cakap sambil bersandar pada atrium tersebut dan melihat ke arah atrium.
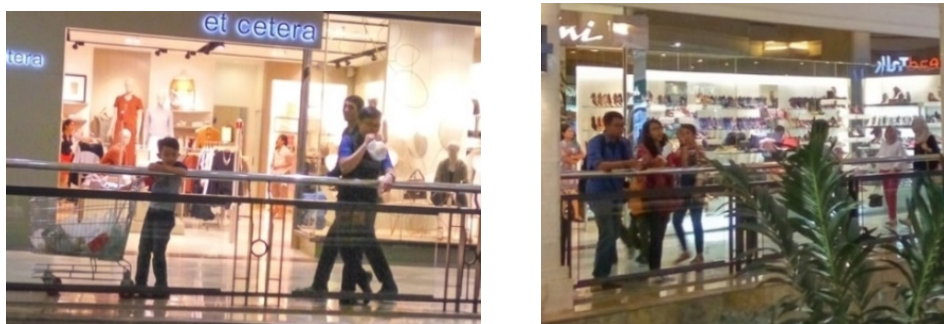

Gambar. 4 Perilaku Pengunjung Pada Railing Ambarrukmo Plaza

(Sumber : Dokumen Pribadi, 3 Oktober 2016)

Pengunjung duduk di kursi yang disediakan oleh mall di sepanjang selasar lantai dua. Terlihat pengunjung yang duduk berdua sedang bercakap-cakap dan yang duduk sendirian sedang bermain gadget.
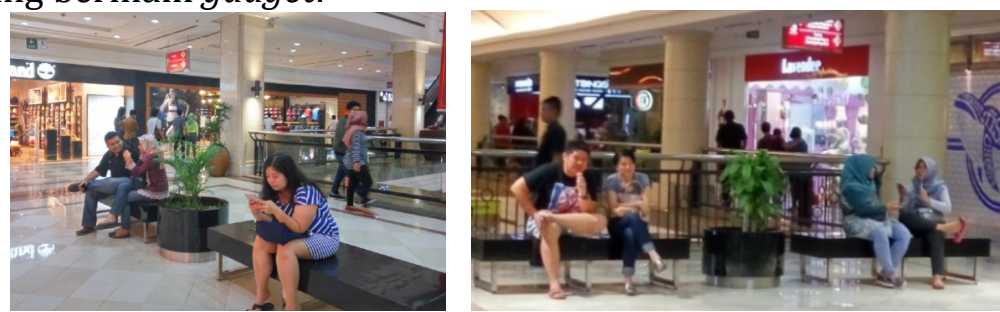

Gambar. 5 Perilaku Pengunjung Pada Area Duduk Ambarrukmo Plaza (Sumber : Dokumen Pribadi, 3 Oktober 2016) 
Pengunjung terlihat bersama keluarga sedang duduk di kursi yang berada di selasar lantai 3 sambil bermain dengan anak yang masih kecil.

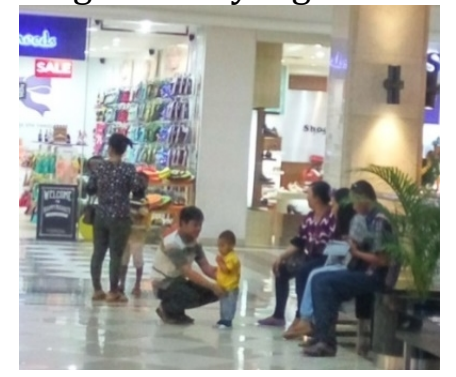

Gambar. 6 Perilaku Pengunjung Pada Area Duduk Ambarrukmo Plaza

(Sumber : Dokumen Pribadi, 3 Oktober 2016)

\subsection{Rumusan Masalah}

Dari latar belakang masalah yang telah diuraikan maka didapatkan rumusan permasalahan sebagai berikut: Bagaimana keterkaitan desain ruang publik dengan perilaku pengunjung pada mall?

\subsection{Metode}

Metode penelitian yang digunakan dalam penelitian ini adalah penelitian diskriptif kualitatif tentang perilaku pengunjung pada ruang publik mall. Penelitian ini menggunakan sistem pengamatan secara sistematis, faktual dan akurat mengenai faktafakta tentang perilaku pengunjung pada ruang publik mall.

Teknik pengumpulan data dalam penelitian ini dengan melakukan observasi lapangan dengan mengamati, mencatat dan menganalisis tingkah laku individu secara langsung. Teknik pengambilan sampel dilakukan dengan purposive sampling yaitu sampel yang dilakukan dengan cara mengambil subyek bukan didasarkan atas strata, random atau daerah tetapi didasarkan atas adanya tujuan tertentu (Hasanah, 2016). Dalam hal ini menggunakan teknik behavior mapping yaitu place-centered mapping. Teknik ini digunakan untuk mengetahui bagaimana manusia atau sekelompok manusia memanfaatkan, menggunakan dan mengakomodasikan perilakunya dalam suatu waktu di tempat tertentu. Langkah-langkah yang harus dilakukan di teknik ini adalah (Adhitama, 2013):

1. Membuat persebaran jenis aktifitas

2. Membuat pelaku kegiatan

3. Membuat jenis kegiatan dan pelakunya

\section{Hasil dan Diskusi}

Pengembangan mal bukan lagi sekadar memiliki tujuan fungsional, namun menjadi lebih bersifat rekreatif. Pusat-pusat perbelanjaan terbaru memiliki fungsi yang lebih kompleks dibandingkan dengan yang sebelumnya. Sisi fungsional dari mal adalah untuk melayani transaksi ekonomi dalam mengakomodasi hubungan antara entitas bisnis (penjual) dan pengunjung (pembeli). Fungsi lainnya adalah untuk menciptakan tempat yang menarik yang membawa kesan ikonik dan unik kepada pengunjung dengan desain arsitektur dan interiornya. Untuk fungsi tempat rekreasi mal harus memiliki ruang fisik yang unik dan nyaman untuk melakukan interaksi sosial. Untuk mencapai fungsi ini, ruang di mal harus menjadi tempat umum yang jauh dari tenang (Kusumowidagdo et al., 2012). 
Faktor-faktor yang harus ada di setiap mal adalah atrium yang mudah ditemukan, citra sosial, dan interaksi. Atrium mewakili karakteristik spasial dari pusat perbelanjaan. Citra sosial dan interaksi difokuskan pada aspek sosial desain, seperti kepadatan pengunjung dan gaya hidup pengunjung, serta etnisitas dan segmentasi mereka di pusat perbelanjaan. Sedangkan untuk dekorasi atrium, dekorasi yang melekat pada elemen interior dapat dalam bentuk fitur yang ditemukan di langit-langit dan pola lantai (Kusumowidagdo dan Sachari, 2015).

Pada Ambarrukmo plaza terdapat perilaku pengunjung yang berada pada ruang publik mall. Perilaku tersebut ada ketika mereka sekedar berjalan-jalan bersama teman maupun keluarga. Bagi sebagian orang berbelanja adalah kegiatan sosial, di mana pengunjung dapat berinteraksi dengan keluarga, teman, atau bahkan pengunjung lain (Davis dan Hodges, 2012). Pengaruh psikologi lingkungan dalam menganalisis dan mengkarakterisasi interaksi orang-lingkungan dan/ atau transaksi pada tingkat lingkungan yang berbeda dapat dipahami dengan baik melalui persepsi, kebutuhan, peluang, dan sarana kontrol (Gifford, 2012). Dari hasil pengamatan maka di dapatkan dua zona dalam ruang publik mall, yaitu zona A yang terletak di sekitar atrium utama dan zona B yang terletak dianatara pertokoan dan atrium kecil. Analisis yang dilakukan adalah Place-Centered Maps yaitu dengan melihat cara pengunjung memanfaatkan, menggunakan atau mengakomodasikan ruang publik.

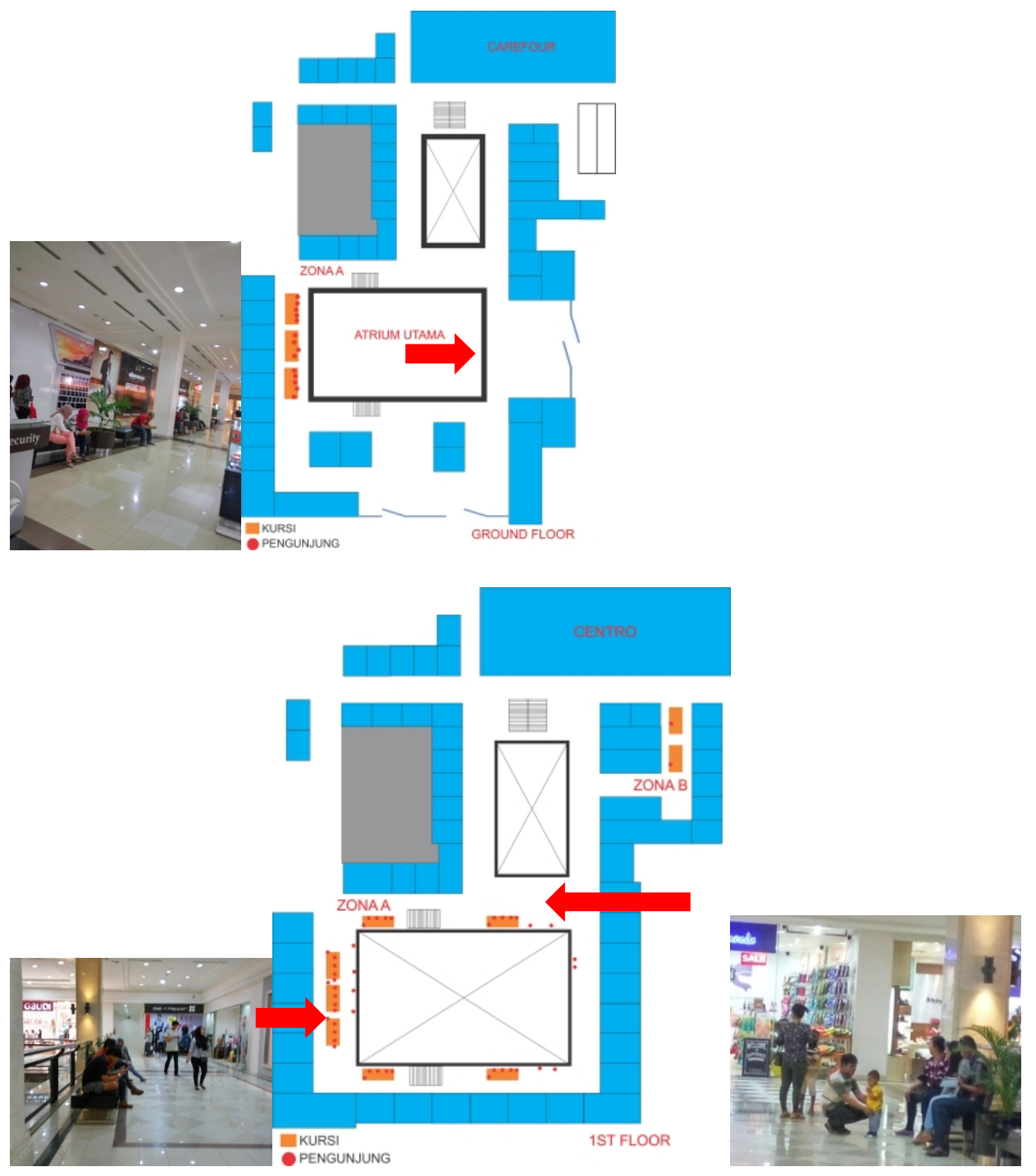



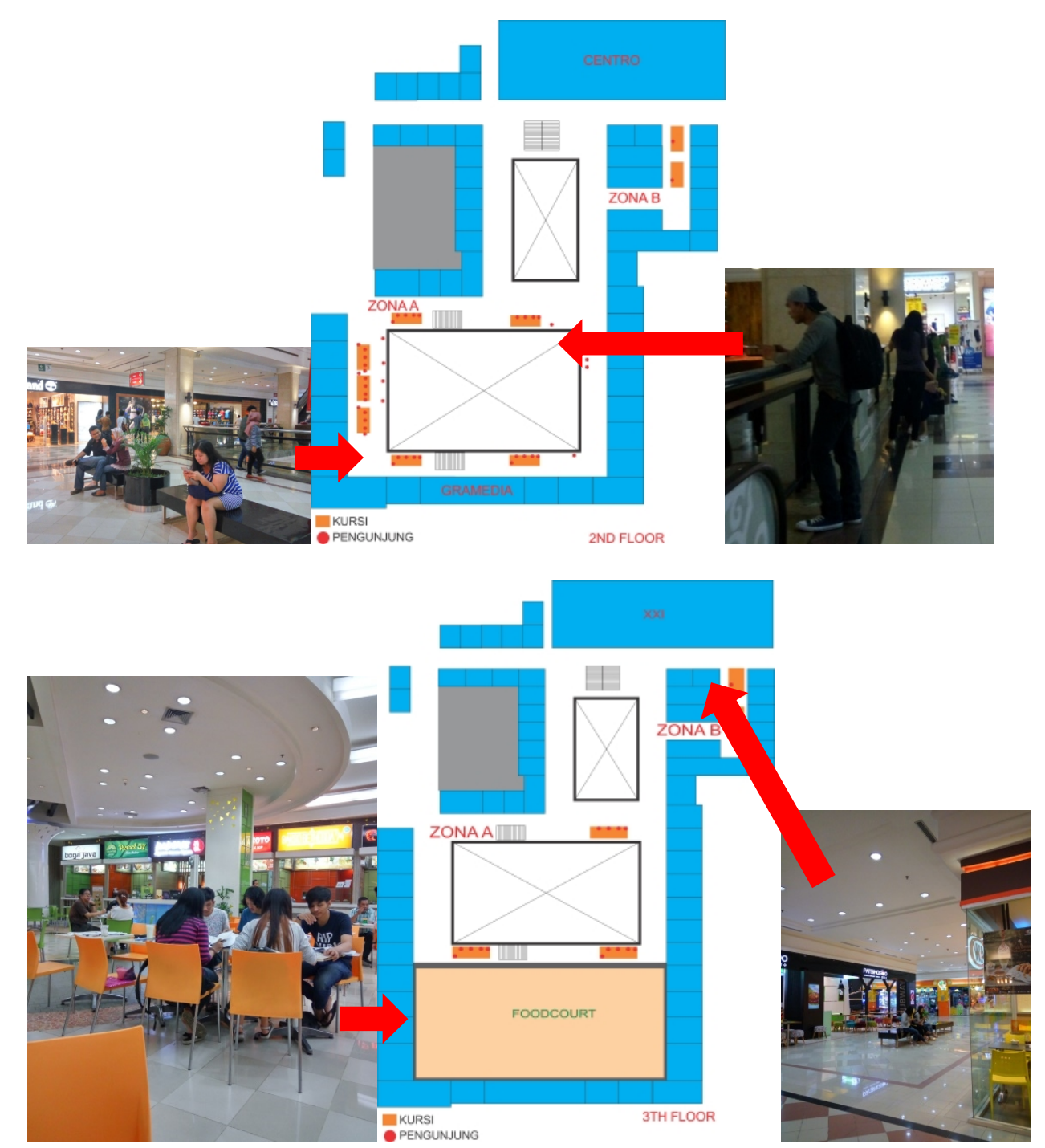

Gambar. 7 Behaviour Mapping Pengunjung Ambarrukmo Plaza

(Sumber : Analisis Penulis, 2016)

Pada Ambarrukmo Plaza pada setiap lorong selasar terdapat kursi. Pada selasar lantai satu, dua dan tiga Ambarrukmo Plaza diberikan kursi-kursi dengan lebar $60 \mathrm{~cm}$. dan railing yang berada di selasar adalah $80 \mathrm{~cm}$, dan lebar selasar $6 \mathrm{~m}$. Ada yang menghadap ke arah atrium dan ada yang menghadap ke arah toko-toko. Terlihat pada mapping diatas bahwa pengunjung paling banyak menempati kursi yang menghadap ke arah atrium. Walaupun selain itu pada area tersebut memiliki lebar selasar yang cukup memadai untuk melihat ke arah toko. Akan tetapi terlihat pada zona B bahwa kursi yang berada di antara toko-toko tidak terlalu diminati pengunjung. Pada zona A merupakan atrium utama sehingga semua kegiatan terpusat pada atrium tersebut, dan pad zona B terdapat atrium kecil yang hanya terdapat penjual yang tetap pada bagian atrium. Dari perbedaan atrium ini maka dapat dilihat bahwa pada railing yang berbatasan dengan atrium utama digunakan untuk para pengunjung melihat acara yang ada di atrium. Sedangkan pada railing area atrium 2, tidak ada pengunjung yang bersandar pada railing dan melihat ke arah atrium.Pada area foodcourt karena desainnya berbentuk terbuka dan berbatasan langsung dengan atrium utama, maka digunakan pengunjung untuk kegiatan lainnya yaitu kegiatan belajar atau hanya sekedar kegiatan mengobrol.

Atmosfer holistik yang ditemui dalam lingkungan mal berkontribusi pada penciptaan pengalaman di dalam mal. Lantai, perabotan interior, tata letak, pencahayaan, 
musik, dan suhu adalah isyarat atmosfer yang dapat menghibur pengunjung di sebuah toko. Pengunjung menyebutkan bahwa memiliki beberapa perabot atau pajangan tambahan di pada mal menciptakan perasaan nyaman dan meningkatkan niat mereka untuk tinggal di toko. Tata letak yang luas dan pencahayaan lembut juga menciptakan perasaan nyaman di dalam mal, sedangkan mal yang sempit, dan pencahayaan yang terang membuatnya tidak nyaman (Ballantine et al., 2015).

Pada Galeria Mall terdapat satu zona yang terletak pada area sekitar atrium Sebagai ruang publik, atrium dapat dikategorikan sebagai tempat publik semu, yang berarti bahwa atrium adalah ruang publik yang dikelola oleh organisasi swasta . Bentuk atrium juga merupakan faktor yang berkontribusi terhadap rasa suatu tempat. Semakin unik bentuknya, semakin baik dapat membedakan mal tersebut dari pusat-pusat perbelanjaan lainnya, dan semakin baik pula terbentuknya sense of place pada pengunjung (Kusumowidagdo dan Sachari, 2015). Analisis yang dilakukan adalah PlaceCentered Maps yaitu dengan melihat cara pengunjung memanfaatkan, menggunakan atau mengakomodasikan ruang publik.

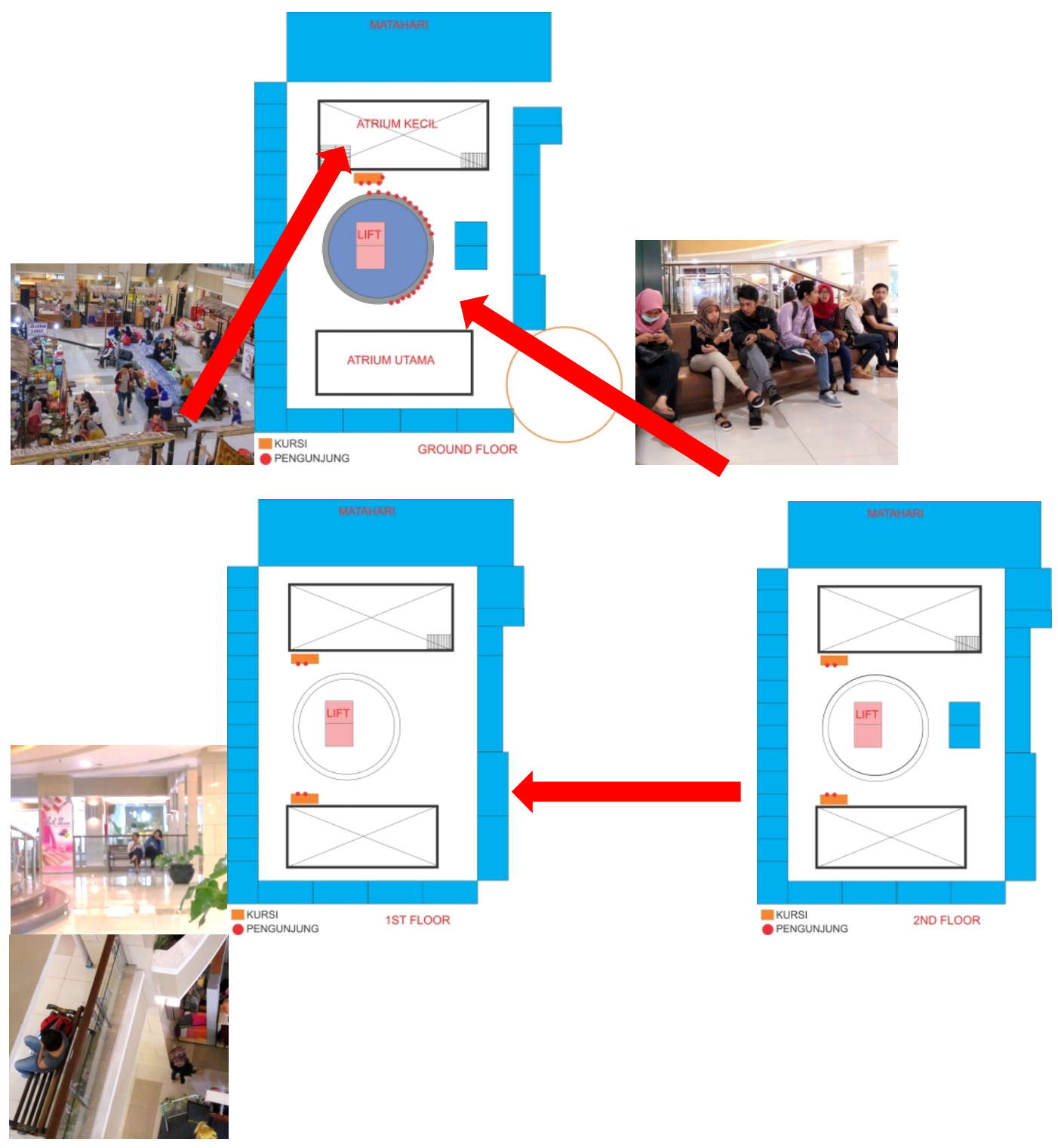




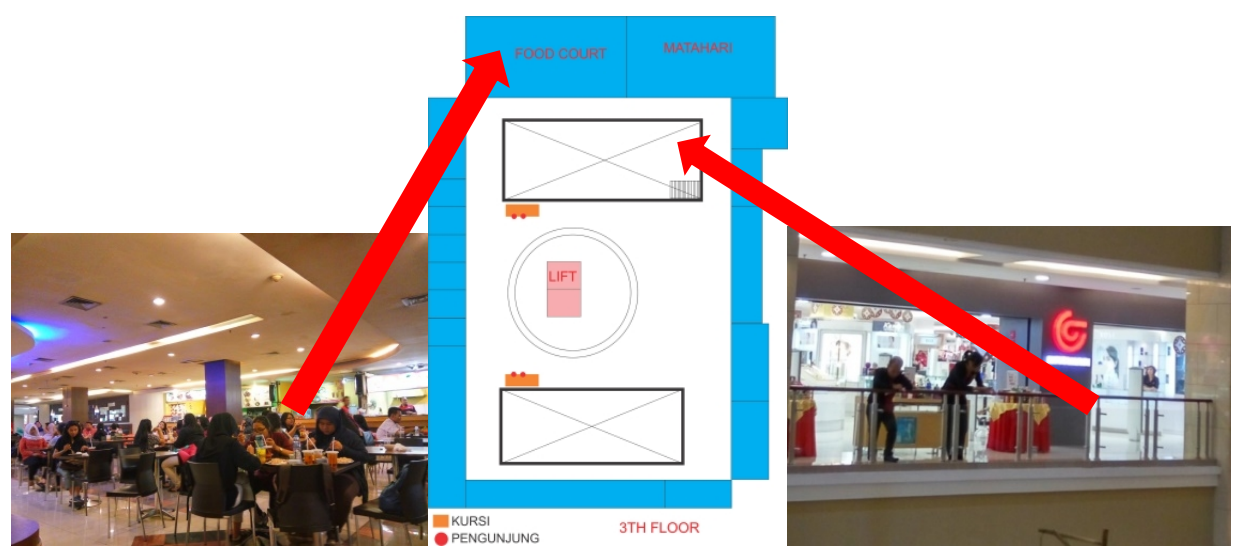

Gambar. 8 Behaviour Mapping Pengunjung Ambarrukmo Plaza

(Sumber : Analisis Penulis, 2016)

Pada Galeria Mall Pada atrium lantai 1 terdapat tempat duduk melingkar yang berada di dekat lift. Lantai dua daan 3 hanya terdapat dua buah tempat duduk. Dengan lebar $40 \mathrm{~cm}$. tinggi railing pada selasar adalah $80 \mathrm{~cm}$. Pada ground floor terdapat tempat duduk melingkar dan pengunjung banyak yang duduk di area tersebut serta menghadap ke arah atrium. Karena pada tempat duduk tersebut berada di antara dua atrium. Pada lantai 2 dan lantai 3 terdapat tempat duduk yang menghadap ke arah selasar dan kursinya memiliki sandaran. Hal itu menyebabkan pengunjung merasa malas memilih duduk di area tersebut karena mereka tidak dapat melihat ke arah atrium. Pengunjung juga memanfaatkan railing yang berada di area sekeliling atrium untuk melihat ke arah atrium. Food court pada Galeria mall memiliki ruangan sendiri dan letaknya menjorok ke dalam sehingga pengunjung berada di dalam food court hanya untuk kegiatan makan.

Mal harus dapat menciptakan sense of place melalui berbagai cara. Perasaan tempat dibentuk oleh faktor fisik dan sosial. Perasaan fisik tempat dapat dicapai dengan menciptakan bentuk spasial yang menarik. Hubungan pengunjung dengan suatu tempat dan pengunjung harus dapat merasakan sensasi yang berbeda bersama dengan kedalaman dan tingkat makna yang berbeda (Najafi dan Shariff, 2011).

\section{Simpulan}

Dari behavior mapping yang diterapkan dalam melihat perilaku pengunjung pada Ambarrukmo plaza dan Galeria mall maka di dapatkan keterkaitan desain ruang publik dengan perilaku pengunjung pada mall, yaitu :

1. Desain ruang publik yang mengitari atrium mall dapat membuat pengunjung yang berada di dalam mall merasa tertarik untuk melihat ke arah atrium.

2. Kursi yang berada di sekeliling atrium utama dan tidak memiliki sandaran dapat membuat pengunjung duduk dan menghadap ke arah atrium utama. Sedangkan kursi yang memiliki sandaran dan berorientasi pada selasar sangat jarang digunakan pengunjung untuk duduk.

3. Kursi yang diletakkan pada area publik di sekitar toko tidak membuat pengunjung memiliki keinginan untuk duduk dan bersantai.

4. Railing yang ada di sekitar atrium utama dan memiliki banyak kegiatan berpotensi digunakan pengunjung untuk bersandar dan melihat ke arah atrium utama.

5. Bentuk desain food court yang terbuka dan berbatasan langsung dengan atrium dapat menimbulkan kegiatan baru selain makan, yaitu belajar kelompok maupun sekedar mengobrol antar teman. 
Pada Ambarrukmo Plaza dan Galeria Mall menggunakan ruang sosiopetal dengan pengaturan ruangan yang cenderung untuk menyatukan individu sehingga tercipta interaksi sosial. Hal itu berfungsi untuk menciptakan efek psikologis kepada pengunjung sehingga mereka tidak merasa terasing di lingkungan yang telah dibuat oleh pengelola mall.

\section{Daftar Pustaka}

Adhitama, M. S. (2013). Faktor Penentu Setting Fisik Dalam Beraktifitas di Ruang Terbuka Publik 'Studi Kasus Alun - Alun Merdeka Kota Malang,' RUAS Vol 11, No 2 Desember 2013.

Davis, L. dan Hodges, N. (2012). Consumer shopping value: An investigation of shopping trip value, in-store shopping value and retail format. Journal of Retailing and Consumer Services Volume 19, Issue 2, March 2012, Pages 229-239 https://doi.org/10.1016/j.jretconser.2012.01.004 .

Gifford, R. (2012). Environmental Psychology, November 2012.

Hasanah, H. (2016). TEKNIK-TEKNIK OBSERVASI (Sebuah Alternatif Metode Pengumpulan Data Kualitatif Ilmu-ilmu Sosial), At-Taqaddum, Volume 8, Nomor 1, Juli 2016.

Kusumowidagdo, A., Sachari, A., dan Widodo, P. (2012). Shoppers' Perception on Physical Condition of Shopping Centers' Atmosphere at Different Lifecycle, International Research Journal of Business Studies, vol 5 no.2, 2012.

Kusumowidagdo, A. dan Sachari, A. (2015). Visitor preference factors toward shopping centres' thematic corridor. Study of Gandaria City, Indonesia shopping centre, Journal of Arts \& Humanities, Vol 4, No 7, 2015.

Najafi, M. dan Shariff, M. K. B. M. (2011). The concept of place and sense of place in architectural studies, World Acad. Sci. Eng. Technol., vol. 80, no. 8, pp. 1100-1106, 2011.

Syoufa, A., Hapsari, H. (2014). Pengaruh Pola Sirkulasi Pusat Perbelanjaan Mall Terhadap Pola Penyebearan Pengunjung, Jurnal Desain Konstruksi, Vol. 13, No. 2, pp. 46-57, 2014. 